\title{
UJI PENGARUH VARIASI KONSENTRASI PERENDAMAN LARUTAN ASAM JAWA TERHADAP PENURUNAN KADAR FORMALIN PADA SOSIS
}

\section{(THE INFLUENCE TEST OF SOAKING CONCENTRATION VARIANCE SOLUTION OF TAMARIND TO REDUCE LEVELS OF FORMALDEHYDE ON SAUSAGE)}

\author{
DEBBY JULIADI*•, NI WAYAN YULIASIH*, DEWA AYU IKA PRAMITHA*, \\ NI PUTU DEWI AGUSTINI*
}

*Akademi Farmasi Saraswati DenpasarJalan Kamboja no. 11A, Denpasar, Bali

\begin{abstract}
Abstrak: Sosis merupakan salah satu bahan pangan olahan yang berbahan dasar daging yang memiliki daya simpan yang relatif singkat. Sehingga dengan alasan tersebut banyak produsen yang menambahkan bahan pengawet pada produk hasil olahannya dan tidak menutup kemungkinan bahwa jenis bahan pengawet yang digunakan berupa formalin. Formalin merupakan Bahan Tambahan Pangan (BTP) yang penggunaannya dilarang oleh pemerintah karena berbahaya bagi kesehatan. Kandungan asam dan saponin yang terdapat pada asam jawa kemungkinan dapat dimanfaatkan untuk proses pemutusan ikatan yang terjadi antara formalin dengan protein. Penelitian ini bertujuan untuk mengetahui pengaruh variasi konsentrasi perendaman larutan asam jawa terhadap penurunan kadar formalin pada sosis. Perendaman dengan larutan asam jawa dimaksudkan larutan asam jawa tersebut dapat menyerap kadar formalin yang terkandung dalam sosis. Penelitian ini menggunakan metode eksperimental secara kuantitatif. Perlakuan yang diberikan pada unit eksperimen adalah dengan perlakuan perendaman terhadap sosis berformalin dengan variasi konsentrasi larutan asam jawa yaitu 60\%; 80\%; dan $100 \%$ yang diuji secara kuantitatif menggunakan asam kromatrofat dan $\mathrm{H}_{2} \mathrm{SO}_{4}$ pekat dengan metode Spektrofotometri UV-Vis. Data yang dihasilkan dianalisis dengan uji statistik inferensial parametrik one way Anova dengan Posthoct Test menggunakan Tukey HSD dan Bonferroni. Penurunan kadar formalin pada sosis setelah perendaman dengan larutan asam jawa pada konsentrasi $60 \%$; 80\%; dan $100 \%$ berturut-turut sebanyak 12,7\%; 38,7\%; dan 45,3\%. Hasil dari penelitian ini menunjukkan bahwa ada pengaruh perendaman dengan variasi konsentrasi larutan asam jawa pada konsentrasi $80 \%(\mathrm{P}=0,000)$ dan $100 \%(\mathrm{P}=0,000)$ berdasarkan uji statistik inferensial parametrik one way Anova.
\end{abstract}

Kata kunci: asam jawa, asam kromatrofat, formalin, sosis, Spektrofotometri UV-Vis

\begin{abstract}
Sausage is one of the processed foods based on meat that has a relatively short shelf life. So, for that reason, many manufacturers added preservatives to the processed products and did not rule out that the type of preservative used in form of formaldehyde. Formaldehyde is a Food Additive Substance that the government prohibits its use because it is harmful to health. The process of breaking the bonds that occur between formaldehyde and protein used acid and saponins that contained in Tamarind. This study aims to determine the influence of soaking concentration variance of Tamarind solution to reduce the formaldehyde level in sausage. This research uses quantitative experimental method. Soaking with tamarind solution is intended to absorb the levels of formalin contained in sausage. The treatment given in the experimental unit is by the soaking treatment of the formaldehyde in sausage with the concentration of Tamarind solution that is $60 \%, 80 \%$, and $100 \%$, were quantitatively tested using chromatrophic acid and concentrated sulfuric acid by UV-Vis Spectrophotometry method. The resulting data were analyzed by inferential statistical test of parametric one way Anova with Posthoct Test using Tukey HSD and Bonferroni. Decreased levels of formaldehyde in sausages after soaking with a solution of Tamarind at a concentration of $60 \%$; $80 \%$; and $100 \%$ consecutively as much as $12.7 \%$; $38.7 \%$; and $45.3 \%$. The results of this study indicate that there is an effect of soaking with variation concentration of Tamarind solution based on inferential statistical test of parametric one way Anova at concentration $80 \%(\mathrm{P}=0.000)$ and $100 \%(\mathrm{P}=$ $0,000)$
\end{abstract}

Keywords: chromotophic acid, formaldehyde, sausage, tamarind, UV-Vis Spectrophotometry

•Author correspondence. Hp: +6281236564646; e-mail: debby.eternity46@gmail.com 


\section{PENDAHULUAN}

Salah satu jenis makanan yang digemari seluruh lapisan masyarakat adalah sosis. Sosis merupakan salah satu bahan pangan olahan yang berbahan dasar dari daging yang memiliki daya simpan yang relatif singkat. Sosis ayam pada suhu $10^{\circ} \mathrm{C}$ hanya memiliki waktu simpan 21 hari sedangkan pada suhu $25^{\circ} \mathrm{C}$ memilki waktu simpan 1 hari (Salim, 2014). Sehingga dengan alasan tersebut banyak produsen yang menambahkan bahan pengawet pada produk hasil olahannya dan tidak menutup kemungkinan bahwa jenis bahan pengawet yang digunakan berupa formalin.

Dalam Peraturan Menteri Kesehatan Republik Indonesia Nomor 033 Tahun 2012 tentang Bahan Tambahan Pangan, formalin dilarang untuk digunakan sebagai Bahan Tambahan Pangan (BTP). Penggunaan formalin sebagai pengawet bahan makanan dewasa ini bukan sesuatu hal yang tabu lagi. Banyak bahan makan seperti ikan asin, tahu, ikan segar, cumi, bakso, dan mie yang beredar dipasaran telah teridentifikasi mengandung formalin dengan kisaran kadar yang bervariasi mulai dari 0,331907,44 ppm (Cahyadi, 2012).

Formalin merupakan larutan jernih tidak berwarna, berbau tajam, mengandung senyawa formaldehid (HCO) sekitar 37\% dalam air (Purawisastra, 2011). Kandungan formalin yang tinggi dalam tubuh juga menyebabkan iritasi lambung, alergi, bersifat karsinogenik (menyebabkan kanker) dan bersifat mutagen (menyebabkan perubahan fungsi sel atau jaringan), diare bercampur darah, kencing bercampur darah, dan kematian yang disebabkan adanya kegagalan peredaran darah (Cahyadi, 2012).

Berdasarkan bahaya yang ditimbulkan dan banyaknya kasus yang ditimbulkan oleh penyalahgunaan formalin sebagai bahan pengawet makanan. Maka, perlu adanya tindakan pencegahan sebagai langkah dini agar dapat melindungi masyarakat dari dampak buruk formalin. Formalin dalam sosis akan berikatan dengan protein yang terkandung pada daging.

Asam jawa merupakan salah satu buah yang mengandung berbagai jenis kandungan asam dan mengandung juga senyawa saponin. Kandungan asam yang terdapat pada asam jawa kemungkinan dapat dimanfaatkan untuk proses pemutusan ikatan yang terjadi antara formalin dengan protein dan senyawa saponin yang terkadung dapat mengikat formalin pada makanan. Namun saat ini, efektivitas larutan asam jawa dalam menurunkan kadar formalin pada makanan belum banyak diteliti. Maka dari itu dalam penelitian ini akan dilakukan penelitian pengaruh perendaman larutan asam jawa terhadap penurunan kadar formalin pada sosis dengan variasi konsentrasi larutan asam jawa.

Penelitian ini bertujuan untuk mengetahui pengaruh variasi konsentrasi larutan asam jawa terhadap penurunan kadar formalin yang terdapat dalam sosis secara kuantitatif dan mengetahui persentase penurunan kadar formalin pada sosis setelah perendaman dengan larutan asam jawa konsentrasi $60 \%, 80 \%$ dan $100 \%$.

\section{ALAT, BAHAN DAN METODE}

Rancangan Penelitian. Penelitian ini menggunakan metode eksperimental secara kuantitatif. Perlakuan yang diberikan pada unit eksperimen adalah perlakuan perendaman terhadap sosis berformalin dengan variasi konsentrasi larutan asam jawa yaitu $60 \%, 80 \%$ dan $100 \%$ untuk melihat pengaruh perendaman dan persentase penurunan kadar formalin pada sosis berformalin setelah dilakukan perlakuan perendaman dengan larutan asam jawa yang diuji secara kuantitatif menggunakan pereaksi asam kromatrofat dan $\mathrm{H}_{2} \mathrm{SO}_{4}$ pekat dengan metode Spektrofotometri UV-Vis.

Alat. Alat yang digunakan dalam penelitian ini adalah Spektrofotometer UV-Vis (Mapada Double Beam Spectrophotometer UV 6100), timbangan analitik (ACIS AD-2100H), beaker glass $250 \mathrm{ml}$ (Herma), labu tentukur $1000 \mathrm{ml}$ (Pyrex); $100 \mathrm{ml}$ (Herma); $10 \mathrm{ml}$ (Pyrex); $5 \mathrm{ml}$ (Herma), pipet ukur10 ml; $5 \mathrm{ml} ; 2 \mathrm{ml} ; 1 \mathrm{ml}$ (Pyrex), gelas ukur $10 \mathrm{ml}$ (Herma), rubber bulb filler, pipet tetes, mortir dan stamper, kertas saring, kain kasa, corong kaca, tabung reaksi (Pyrex), rak tabung reaksi, toples kaca, botol semprot, cawan porselen, almari asam, kertas perkamen, aluminium foil, sendok tanduk.

Bahan. Bahan yang digunakan dalam penelitian ini adalah sosis ayam dengan merk Tora yang diperoleh dari Rumah Sosis Salam di Jalan Batukaru Denpasar, daging buah asam jawa, formalin 37\% (Brataco), larutan pereaksi Tollens, larutan Fehling A (Brataco), larutan Fehling B (Brataco), asam kromatrofat (Merk Germany), $\mathrm{H}_{2} \mathrm{SO}_{4}$ pekat (Brataco), aquadest.

\section{Metode.}

1. Penyiapan Bahan Baku dan Pereaksi

a. Pembuatan larutan baku induk. Dibuat larutan baku induk dengan konsentrasi 1000 ppm dengan cara dipipet 2,7 $\mathrm{ml}$ larutan 
formalin $37 \%$, dimasukkan ke dalam labu ukur $100 \mathrm{ml}$ dan ditambahkan aquadest sampai tanda batas untuk konsentrasi 10.000 ppm. Untuk memperoleh konsentrasi 1000 ppm dilakukan pengenceran dengan cara memipet $10 \mathrm{ml}$ larutan formalin $10.000 \mathrm{ppm}$, dimasukkan ke dalam labu ukur $100 \mathrm{ml}$ dan ditambahkan aquadest sampai tanda batas.

Dibuat larutan formalin dengan konsentrasi $0,2 \%$ dalam volume $1000 \mathrm{ml}$ untuk merendam sampel, dengan cara dipipet 5,4 $\mathrm{ml}$ larutan formalin $37 \%$, dimasukkan ke dalam labu ukur $1000 \mathrm{ml}$ dan ditambahkan aquadest sampai tanda batas.

b. Pembuatan larutan baku kerja. Dari larutan baku induk dilakukan pengenceran untuk membuat larutan baku kerja dengan konsentrasi $100 ; 50: 25 ; 20 ; 15 ; 10 ; 5 ; 3 ; 2$; 1,$75 ; 1,5 ; 1,25 ; 1 ; 0,75 ; 0,5 ; 0,1 ; 0,05$ ppm.

c. Pembuatan pereaksi Asam Kromatrofat. Dibuat pereaksi asam kromatrofat dengan cara ditimbang $40 \mathrm{mg}$ serbuk asam kromatrofat dimasukkan ke dalam labu ukur $10 \mathrm{ml}$, Kemudian ditambahkan akuades sampai tanda batas.

d. Pembuatan larutan blangko. Diambil sebanyak $2 \mathrm{ml}$ larutan asam kromatrofat dimasukkan dalam tabung reaksi ditambahkan $2 \mathrm{ml} \mathrm{H}_{2} \mathrm{SO}_{4}$ pekat, homogenkan.

e. Pembuatan pereaksi Fehling. Diambil sebanyak $2 \mathrm{ml}$ Fehling A ditambahkan $2 \mathrm{ml}$ larutan Fehling $B$ akan terbentuk larutan berwarna biru tua.

f. Penyiapan sampel simulasi. Dipotong sosis kemudian ditimbang beratnya sebesar 18 gram. Kemudian sebanyak 20 sosis direndam dengan larutan formalin dengan konsentrasi $0,2 \%$ selama 24 jam dalam wadah tertutup rapat.

\section{Penentuan Panjang Gelombang} Maksimum. Larutan formalin 2 ppm dipipet sebanyak $2 \mathrm{ml}$ dimasukkan kedalam tabung reaksi, kemudian ditambahkan 0,2 ml larutan asam kromatrofat dan ditambahkan $3 \mathrm{ml}$ $\mathrm{H}_{2} \mathrm{SO}_{4}$ pekat, dihomogenkan dan diinkubasi pada suhu kamar selama \pm 5 menit. Kemudian diukur absorbansinya dengan Spektrofotometer UV-Vis pada panjang gelombang 400-800 $\mathrm{nm}$.
3. Pembuatan Kurva Regresi. Pembuatan kurva regresi diukur dari serapan larutan formalin, kemudian dibuat garis lurus yang menghubungkan konsentrasi dengan absorbansi (serapan) dan diperoleh sebuah persamaan $\mathbf{y}=\mathbf{b x}+\mathbf{a}$.

4. Pengujian Sosis secara Kualitatif. Disiapkan 6 sampel sosis, kemudian dihancurkan menggunakan mortar dan stamper kemudian diperas menggunakan kain kasa. Ditampung air hasil perasan sampel dalam cawan porselen untuk kemudian diuji dengan pereaksi Tollens dan Fehling. Masing-masing pengujian menggunakan 3 sosis.

a. Dengan pereaksi Fehling

Larutan Fehling ditambahkan $2 \mathrm{ml}$ sampel kemudian dipanaskan di atas lampu Bunsen.

b. Dengan pereaksi Tollens Larutan tollens ditambahkan 3 tetes sampel. Jika tidak terbentuk cermin perak pada dinding tabung, tabung reaksi dipanaskan di atas penangas air pada suhu $40^{\circ} \mathrm{C}$ selama 5 menit.

\section{Pembuatan Larutan Asam Jawa}

a. Larutan asam jawa dengan konsentrasi 60 $\%$. Sebanyak 60 gram daging buah asam jawa digerus menggunakan mortar dan stamper kemudian ditambahkan aquadest sampai $100 \mathrm{ml}$.

b. Larutan asam jawa dengan konsentrasi $80 \%$. Sebanyak 80 gram daging buah asam jawa digerus menggunakan mortar dan stamper kemudian ditambahkan aquadest sampai $100 \mathrm{ml}$.

c. Larutan asam jawa dengan konsentrasi $100 \%$ Sebanyak 100 gram daging buah asam jawa digerus menggunakan mortar dan stamper kemudian ditambahkan aquadest sampai $100 \mathrm{ml}$.

6. Perlakuan Uji Skrining Kandungan Saponin pada Larutan Asam Jawa. Sebanyak $5 \mathrm{ml}$ larutan asam jawa dengan konsentrasi masing-masing 60\%, 80\% dan $100 \%$ ditempatkan pada tabung reaksi kemudian dikocok selama 10 detik dan diamati busa yang timbul selama 10 menit.

7. Pengujian Kadar Awal Formalin. Lima potong sosis yang telah direndam selama 24 jam dalam larutan formalin konsentasi $0,2 \%$ dihancurkan dengan menggunakan mortar dan stamper, selanjutnya diperas menggunakan kain kasa dan ditampung air perasan sampel dalam cawan porselen untuk 
diukur kadar awal formalin. Dipipet sebanyak $1 \mathrm{ml}$ supernatan, kemudian dimasukkan ke dalam labu ukur $100 \mathrm{ml}$ dan ditambahkan aquadest sampai tanda batas. Selanjutnya, sebanyak $2 \mathrm{ml}$ larutan sampel dimasukkan ke dalam tabung reaksi, ditambahkan $0,2 \mathrm{ml}$ asam kromatrofat dan $3 \mathrm{ml} \mathrm{H}_{2} \mathrm{SO}_{4}$ pekat, dihomogenkan dan diinkubasi pada suhu kamar selama \pm 5 menit, kemudian diukur kadarnya dengan Spektrofotometer UV-Vis.

8. Pengujian Kadar Akhir Formalin setelah Perlakuan Perendaman dengan Larutan Asam Jawa. Sebanyak 5 sampel sosis yang telah direndam selama 24 jam dalam larutan formalin konsentasi $0,2 \%$ diberi perlakuan dengan melakukan perendaman dengan larutan asam jawa konsentrasi $60 \%, 80 \%$ dan $100 \%$ selama 60 menit. Kemudian dihancurkan dengan mortar dan stamper, kemudian diperas dengan kain kasa dan ditampung air perasannya dalam cawan porselen. Sebanyak $1 \mathrm{ml}$ supernatan dimasukkan ke dalam labu ukur $100 \mathrm{ml}$ dan ditambahkan aquadest sampai tanda batas. Sebanyak $2 \mathrm{ml}$ larutan formalin dimasukkan ke dalam tabung reaksi kemudian ditambahkan 0,2 $\mathrm{ml}$ asam kromatrofat dan 3 $\mathrm{ml} \mathrm{H}_{2} \mathrm{SO}_{4}$ pekat, dihomogenkan dan diinkubasi pada suhu kamar selama \pm 5 menit, kemudian diukur kadarnya dengan Spektrofotometer UV-Vis.

9. Pengolahan dan analisis data. Hasil penelitian dianalisis menggunakan uji statistika dengan software SPSS versi 20 melalui uji statistik inferensial parametrik one way Anova dengan Posthoct Test menggunakan Tukey HSD dan Bonferroni dengan taraf kepercayaan 95\%. Perbedaan rata-rata dikatakan signifikan jika nilai $\mathrm{p}<$ 0,05 . Perhitungan persentase penurunan kadar menggunakan rumus:

$\underline{\text { Rata-rata kadar awal - Rata-rata kadar akhir }}$ X $100 \%$

\section{HASIL DAN PEMBAHASAN}

A. Hasil Skrining Saponin Larutan Asam Jawa

Tabel 1. Hasil Uji Organoleptis Larutan Asam Jawa

\begin{tabular}{|c|c|c|c|}
\hline Rasa & Warna & Aroma & Gambar \\
\hline Masam & Coklat & Khas. Buah & \\
& & Asam Jawa & \\
& & & \\
& & & \\
& & & \\
\hline
\end{tabular}

Tabel 2. Hasil Uji Skrining Saponin Larutan Asam Jawa

\begin{tabular}{|c|c|c|c|}
\hline $\begin{array}{c}\text { Larutan } \\
\text { Ksam Jawa } \\
\text { Konsentrasi } \\
60 \%\end{array}$ & $\begin{array}{c}\text { Larutan } \\
\text { Asam Jawa } \\
\text { Konsentrasi } \\
\text { S0\% }\end{array}$ & $\begin{array}{c}\text { Larutan } \\
\text { Asam Jawa } \\
\text { Konsentrasi } \\
100 \%\end{array}$ & Keterangan \\
\hline & & & $\begin{array}{c}\text { Positif } \\
\text { mengandung } \\
\text { saponin. } \\
\text { Busa yang } \\
\text { terbentuk } \\
\end{array}$ \\
& & & $\begin{array}{c}\text { stabil selama } \\
10 \text { menit. }\end{array}$ \\
\hline
\end{tabular}

Tabel 3. Hasil Uji pH Indikator Larutan Asam Jawa

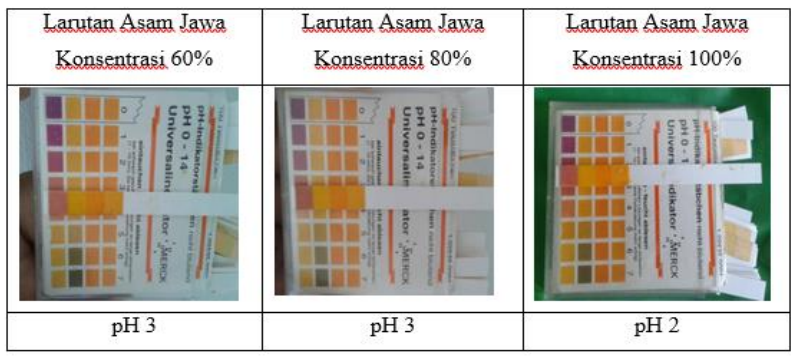

Berdasarkan hasil uji $\mathrm{pH}$ indikator yang dilakukan terhadap larutan asam jawa, menghasilkan nilai $\mathrm{pH}$ dibawah 7 sehingga menunjukkan bahwa larutan asam jawa bersifat asam. Sifat asam ini dikarenakan asam jawa mengandung beberapa jenis asam.

\section{B. Reaksi Formalin dengan Asam} Kromatrofat dan Asam Sulfat Pekat

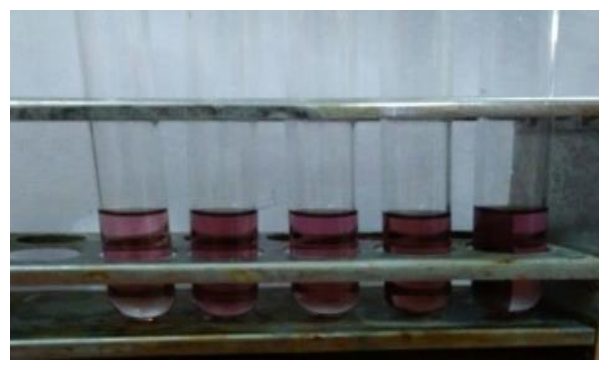


Terbentuknya warna ungu tua atau violet merupakan hasilreaksi secara kondensasi antara formalin (formaldehid) yang mengandung gugus karbonil $(\mathrm{C}=\mathrm{O})$ dengan asam kromatropat (Munson, 1991: Soebito dkk., 1992 dalam Budiarti dkk., 2009).

\section{Hasil Penentuan Panjang Gelombang Maksimum}

Panjang gelombang yang digunakan untuk analisis kuantitatif adalah panjang gelombang yang mempunyai absorbansi maksimal. Hasil pengukuran panjang gelombang serapan maksimum formalin yang diperoleh yaitu $572 \mathrm{~nm}$ yang dipilih berdasarkan nilai serapan tertinggi. Kurva serapan panjang gelombang maksimum formalin dapat dilihat pada Gambar 1 .

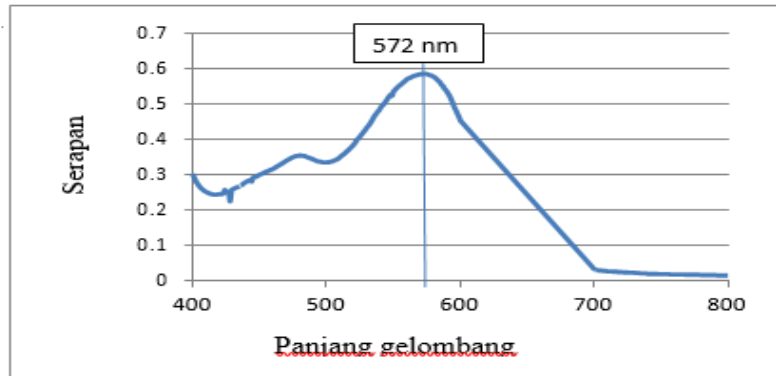

Gambar 1. Kurva Serapan Formalin dengan Panjang Gelombang 572 nm

\section{Kurva Regresi}

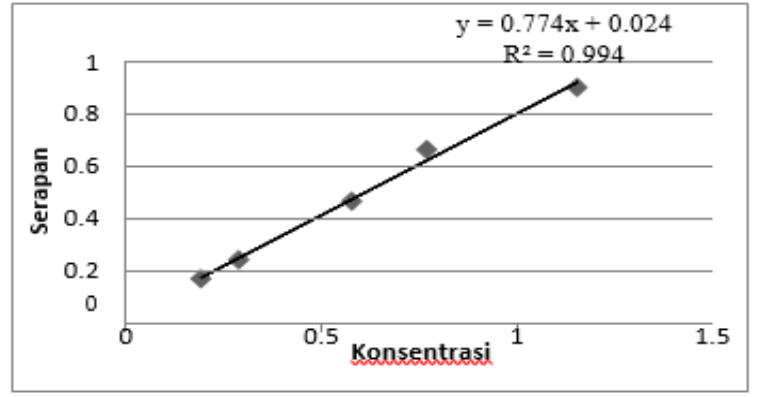

Gambar 2. Reaksi Formalin dengan Asam

Kromatrofat dan Asam Sulfat Pekat

Kurva regresi formalin yang dibuat dari lima konsentrasi formalin bertingkat yaitu 0,$5 ; 0,75$; 1,5; 2 dan 3 ppm. Dari kurva didapatkan persamaan linier antara konsentrasi dan absorbansi formalin yaitu $\mathrm{y}=0,774 \mathrm{x}+0,024$ dengan harga $\mathrm{R}=0,994$. Persamaan Linear tersebut dapat digunakan sebagai penentu konsentrasi formalin dari absorbansi yang diperoleh.

\section{E. Pengujian secara Kualitatif Kandungan} Formalin dalam Sosis

Uji kontrol negatif ini bertujuan untuk membuktikan bahwa sosis yang akan digunakan tidak mengandung formalin.

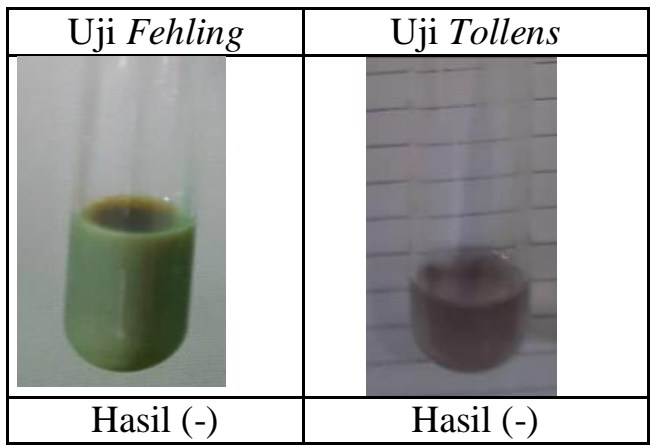

Gambar 3. Hasil Pengujian Sosis dengan Pereaksi Fehling dan Tollens

Keterangan:

Hasil (-) uji fehling ditandai dengan tidak terbentuk endapan berwarna merah dan hasil (-) uji tollens ditandai dengan tidak terbentuk logam perak pada dinding tabung reaksi

F. Hasil Penetapan Kadar Awal sebelum Perlakuan dan Kadar Akhir Formalin pada Sosis setelah Perlakuan Perendaman dengan Larutan Asam Jawa

Pengukuran serapan sosis dilakukan pada panjang gelombang $572 \mathrm{~nm}$ untuk menentukan kadar awal sebelum perlakuan dan kadar akhir formalin dalam sosis setelah perlakuan perendaman dengan larutan asam jawa dengan variasi konsentrasi 60\%, 80\% dan $100 \%$. Pengulangan untuk penentuan kadar awal dan kadar akhir tiap variasi konsentrasi dilakukan sebanyak lima kali. Nilai serapan yang diperoleh kemudian dihitung menggunakan persamaan $\mathrm{y}=0,774 \mathrm{x}+0,024$ sehingga diperoleh hasil sebagai berikut yaitu:

Tabel 4. Hasil Uji Penetapan Kadar Awal Formalin pada Sosis

\begin{tabular}{cc}
\hline Pengulangan & $\begin{array}{c}\text { Konsentrasi } \\
\text { Awal }\end{array}$ \\
\hline 1 & 0,850 \\
\hline 2 & 1,040 \\
\hline 3 & 0,874 \\
\hline 4 & 0,916 \\
\hline 5 & 0,922 \\
\hline Rata-rata (x+ SD) & $0,920 \pm 0,073$ \\
\hline
\end{tabular}


Tabel 5. Hasil Uji Penetapan Kadar Akhir Formalin pada Sosis setelah Perlakuan Perendaman dengan Larutan Asam Jawa

\begin{tabular}{c|c|c|c}
\hline \multirow{2}{*}{ Pengulangan } & \multicolumn{3}{c}{ Konsentrasi Akhir Formalin (ppm) } \\
\cline { 2 - 4 } & $\begin{array}{c}\text { Larutan } \\
\text { Asam } \\
\text { Jawa 60\% }\end{array}$ & $\begin{array}{c}\text { Larutan } \\
\text { Asam } \\
\text { Jawa 80\% }\end{array}$ & $\begin{array}{c}\text { Larutan } \\
\text { Asam } \\
\text { Jawa 100\% }\end{array}$ \\
\hline 1 & 0,813 & 0,595 & 0,468 \\
\hline 2 & 0,811 & 0,598 & 0,661 \\
\hline 3 & 0,753 & 0,642 & 0,521 \\
\hline 4 & 0,899 & 0,392 & 0,501 \\
\hline 5 & 0,740 & 0,591 & 0,364 \\
\hline Rata-rata & $0,803 \pm$ & $0,564 \pm$ & $0,503 \pm$ \\
(x+ SD) & 0,063 & 0,098 & 0,107 \\
\hline
\end{tabular}

\section{G. Persentase Penurunan Kadar Formalin pada Sosis}

Tabel 6. Persentase Penurunan Kadar Formalin dalam Sosis

\begin{tabular}{l|l|l|l}
\hline & $\begin{array}{c}\text { Larutan } \\
\text { Asam } \\
\text { Jawa 60\% }\end{array}$ & $\begin{array}{c}\text { Larutan } \\
\text { Asam } \\
\text { Jawa 80\% }\end{array}$ & $\begin{array}{c}\text { Larutan } \\
\text { Asam } \\
\text { Jawa 100\% }\end{array}$ \\
\hline $\begin{array}{l}\text { Persentase } \\
\text { Penurunan (\%) }\end{array}$ & 12,7 & 38,7 & 45,3 \\
\hline $\begin{array}{l}\text { Sisa Kadar } \\
\text { Formalin dalam } \\
\text { Sosis (\%) }\end{array}$ & 87,3 & 61,3 & 54,7 \\
\hline
\end{tabular}

\section{H. Hasil Uji Statistika Kadar Awal dan Kadar Akhir Formalin pada Sosis setelah Perlakuan}

Tabel 7. Hasil Analisis Statistika Kadar Formalin dalam Sosis sebelum dan sesudah Perendaman dengan Larutan Asam Jawa

\begin{tabular}{|c|c|c|c|}
\hline & & $\mathrm{P}$ & Keterangan \\
\hline \multicolumn{4}{|c|}{ Hasil Uji Tukey HSD } \\
\hline \multirow[t]{3}{*}{ Kadar Awal } & Konsentrasi $60 \%$ & 0,18 & sig $>0,05$ \\
\hline & Konsentrasi $80 \%$ & 0,00 & $\operatorname{sig}<0,05$ \\
\hline & Konsentrasi & 0,00 & $\operatorname{sig}<0,05$ \\
\hline \multirow{2}{*}{$\begin{array}{l}\text { Konsentrasi } \\
60 \%\end{array}$} & Konsentrasi $80 \%$ & 0,00 & $\operatorname{sig}<0,05$ \\
\hline & Konsentrasi & 0,00 & $\operatorname{sig}<0,05$ \\
\hline $\begin{array}{l}\text { Konsentrasi } \\
80 \%\end{array}$ & Konsentrasi & 0,69 & sig $>0,05$ \\
\hline \multicolumn{4}{|c|}{ Hasil Uji Bonferroni } \\
\hline \multirow[t]{3}{*}{ Kadar Awal } & Konsentrasi $60 \%$ & $\begin{array}{c}0,29 \\
7\end{array}$ & sig $>0,05$ \\
\hline & Konsentrasi $80 \%$ & $\begin{array}{c}0,00 \\
0\end{array}$ & $\operatorname{sig}<0,05$ \\
\hline & $\begin{array}{c}\text { Konsentrasi } \\
100 \%\end{array}$ & $\begin{array}{c}0,00 \\
0\end{array}$ & $\operatorname{sig}<0,05$ \\
\hline \multirow{2}{*}{$\begin{array}{l}\text { Konsentrasi } \\
60 \%\end{array}$} & Konsentrasi $80 \%$ & 0,00 & $\operatorname{sig}<0,05$ \\
\hline & Konsentrasi & 0,00 & sig $<0,05$ \\
\hline $\begin{array}{l}\text { Konsentrasi } \\
80 \%\end{array}$ & $\begin{array}{c}\text { Konsentrasi } \\
100 \%\end{array}$ & $\begin{array}{c}1,00 \\
0\end{array}$ & sig $>0,05$ \\
\hline
\end{tabular}

Berdasarkan hasil analisis statistik, diperoleh bahwa antara kadar awal formalin pada sosis dengan kadar akhir formalin dalam sosis setelah perendaman dengan larutan asam jawa konsentrasi $80 \%$ dan $100 \%$ terjadi penurunan kadar formalin dalam sosis yang memiliki atau ada perbedaan bermakna diantara keduanya. Menurut Purawisastra (2011), terjadi reaksi antara protein (asam amino) dengan formalin membentuk senyawa methylene.

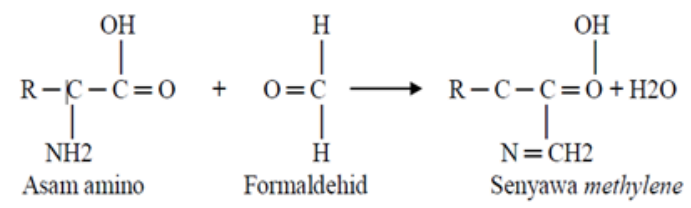

\section{Gambar 6. Reaksi antara Protein dan}

\section{Formalin (Sumber: Purawiastra, 2011)}

Formaldehid adalah senyawa aldehid yang paling sederhana (Fessenden dan Fessenden, 2010). Pemisahan senyawa aldehid dapat dilakukan dengan penambahan asam (Riawan, 1990) dan Menurut Kusumadiana (2006) dalam Muntaha (2015), untuk menghilangkan kadar formalin atau deformalinisasi dapat dilakukan melalui reaksi hidrolisis dan tambahan asam. Berdasarkan dari hal tersebut, maka dimanfaatkan daging buah asam jawa mengandung asam askorbat, asam tartrat, asam maleat, asam sitrat, asam suksinat, dan asam asetat (Khalid dkk., 2009; Livingston dkk., 2008; Pino dkk., 2004; Soedibyo, 1998 dalam Perdana, 2012) untuk pengurangan kandungan formalin dalam sosis.

Menurut Kiernan (2000), bahwa ikatan awal yang terbentuk antara formalin dan protein menghasilkan methyl-alkohol yang ikatannya bersifat reversible sehingga mudah dipecah dengan adanya senyawa asam yang bertindak sebagai penyedia ion $\mathrm{H}^{+}$. Menurut Fessenden dan Fessenden (1982), asam dalam reaksi adisi bertindak sebagai katalis pada reaksi tahap awal protonasi oksigen. Protonasi ini akan menambah muatan positif pada karbon karbonil sehingga karbon ini lebih mudah diserang oleh nukleofil yang lebih lemah sehingga akan melepaskan protonnya ke dalam air.

Selain kandungan berberapa jenis asam, saponin yang terkandung dalam buah asam jawa diduga dapat menurunkan kadar formalin dalam sosis. Menurut Hartati (2015), keberadaan kedua gugus (non polar dan polar) pada surfaktan dalam senyawa saponin, memiliki kualifikasi untuk dapat membentuk emulsi air dan formalin, sehingga saponin berperan sebagai emulgator. Berdasarkan hasil penelitian, dapat dikatakan 
bahwa kandungan asam dan saponin dalam daging buah asam jawa dapat menurunkan kadar formalin dalam sosis yang sebelumnya telah diawetkan dengan formalin melalui proses katalisis dan saponifikasi.

\section{SIMPULAN}

Berdasarkan hasil pengujian secara kuantitatif penurunan kadar formalin pada sosis setelah direndam dengan larutan asam jawa konsentrasi $60 \%$, $80 \%$ dan $100 \%$ menggunakan metode Spektrofotometri UV-Vis dengan pereaksi asam kromatrofat dan asam sulfat pekat dapat disimpulkan bahwa:

1. Terdapat pengaruh perendaman variasi konsentrasi larutan asam jawa terhadap penurunan kadar formalin pada sosis dengan nilai sig yang diperoleh pada uji Tukey HSD dan uji Bonferroni menunjukkan bahwa ada pengaruh perendaman dengan variasi konsentrasi larutan asam jawa pada konsentrasi $80 \%(\mathrm{P}=0,000)$ dan $100 \%(\mathrm{P}=$ 0,000). Penurunan jumlah formalin yang terkandung dalam sosis karena kandungan asam dan saponin pada larutan asam jawa sebagai katalisator dan surfaktan.

2. Persentase penurunan kadar formalin pada sosis setelah perendaman dengan larutan asam jawa pada konsentrasi $60 \%, 80 \%$ dan $100 \%$ berturut-turut sebesar $12,7 \% ; 38,7 \%$ dan $45,3 \%$.

\section{DAFTAR PUSTAKA}

Budiarti.A, Supriyanti, Siti Musinah, 2009, 'Pengaruh Perendaman Dalam Air Hangat Terhadap Kandungan Formalin Pada Mie Basah Dari Tiga Produsen Yang Dijual Di Pasar Johar Semarang', Jurnal Ilmu Farmasi dan Farmasi Klinik, 6(1):1-5

Cahyadi, W. 2012, Analisis dan Aspek Kesehatan Bahan Tambahan Pangan, Edisi II, Bumi Aksara, Jakarta. Indonesia.

Damayanti, E, Farid Ma'ruf, dan Ima Wijayanti, 2014.'Efektivitas Kunyit (Curcuma longa Linn.) Sebagai Pereduksi Formalin Pada
Udang Putih (Penaeus merguiensis) Penyimpanan Suhu Dingin' Jurnal Pengolahan dan Bioteknologi Hasil Perikanan 3(1):98-107

Fessenden dan Fessenden. 2010. Dasar-Dasar Kimia Organik. Terjemahan oleh Sukmariah Maun, Karmianti Anas dan Tilda S. Sally. Jakarta: Binarupa Aksara.

Fessenden dan Fessenden. 1982. Kimia Organik Edisi III Jilid 2. Terjemahan oleh Aloysius Handyana Pudjaatmaka, Erlangga, Jakarta. Indonesia.

Kementerian Kesehatan. 2012, Peraturan Menteri Kesehatan Republik Indonesia, Nomor 033, tentang Bahan Tambahan Pangan, Jakarta, Kementerian Kesehatan Republik Indonesia.

Kiernan, John A. 2000. Formaldehyde, Formalin, Paraformaldehyde, and Glutaraldehyde: What They Are and What They Do. Microscopy Today 00-1: 8-12. (online), viewed $20 \quad$ June 2017 , <http://publish.uwo.ca/ jkiernan/formglut.ht $\mathrm{m}>$.

Muntaha.A, Haitami, Nurul Hayati. 2015, 'Perbandingan Penurunan Kadar Formalin Pada Tahu Yang Direbus dan Direndam Air Panas', Medical Laboratory Technology Journal, 1(2);84-90.

Perdana, R.K. 2012.'Aktivitas Analgetik Infusa Buah Asam Jawa (Tamarindus indica L.) Pada Mencit', Naskah Publikasi, Fakultas Farmasi Universitas Muhammadiyah Surakarta, viewed 21 June 2017, $<$ http;//eprints.ums.ac.id>.

Purawisastra, S dan Sahara, E. 2011, 'Penyerapan Formalin Oleh Beberapa Jenis Bahan Makanan Serta Penghilangannya Melalui Perendaman Dalam Air Panas', PGS, 34(1):70-72.

Riawan, S. 1990. Kima Organik. Edisi ke-1, Binarupa Aksara, Jakarta. Indonesia. 